\title{
ANALISIS PRAKTIK PEMASARAN SUSU SAPI DITINJAU DARI HUKUM ISLAM
}

\section{(Studi Kasus Di Desa Tambang Kecamatan Pudak Kabupaten Ponorogo)}

Muhammad Ulfi, Nurul Fardiana

\author{
Institut Agama Islam Ryadlatul Mujahidin Ngabar (IAIRM) Ponorogo \\ Nurul_fardiana@gmail.com
}

\begin{abstract}
Tambang Village, located in Pudak District, Ponorogo Regency, East Java Province, with a mountainous atmosphere is very suitable for vegetable farmers and cattle ranchers. The marketing of cow's milk in the village of Tambang can help grow the community's economy in the field of dairy farming. Besides that it can also increase ukhuwah Islamiyah between sellers and buyers. The objectives of this study are: (1) Formulate the marketing strategy of cow milk that has been carried out in Tambang Village, Pudak District, Ponorogo Regency (2) Analyzing marketing strategies in Islamic law in Tambang Village Pudak District, Ponorogo Regency in a review of Islamic Law

Based on the results of the study, the marketing strategy of cow's milk in the village of Tambang, Pudak District, Ponorogo Regency, sales transactions are transparent. In marketing cow's milk has positive values including, has a good market and has a partnership with Nestle companies in Pasuruan, Sidoarjo, East Java. The practice of marketing cow milk is reviewed in Islamic law.

At present the constraints experienced by dairy farmers in the mine village, for example: there are no health workers who specifically deal with these problems. In addition, there is a lack of coordination and cooperation between the Tambang village government and the health department in helping public health and livestock as well.
\end{abstract}

Keywords : Marketing of Cow Milk, Islamic Law, Ponorogo

\begin{abstract}
ABSTRAK
Desa Tambang yang terletak di Kecamatan Pudak Kabupaten Ponorogo provinsi Jawa Timur, dengan suasana pegunungan sangat cocok bagi petani sayuran dan peternak sapi. Adanya pemasaran susu sapi di desa Tambang ini dapat membantu menumbuhkan perekonomian masyarakat dalam bidang peternakan sapi perah. Disamping itu juga dapat meningkatkan ukhuwah Islamiyah antara penjual dan pembeli.Tujuan penelitian ini adalah: (1) Merumuskan strategi pemasaran susu sapi yang telah dilakukan di Desa Tambang Kecamatan Pudak Kabupaten Ponorogo (2) Menganalisis strategi pemasaran dalam hukum Islam di Desa Tambang Kecamatan Pudak Kabupaten Ponorogo dalam tinjauan Hukum Islam

Berdasarkan hasil penelitian, Strategi pemasaran susu sapi di desa Tambang, Kecamatan Pudak Kabupaten Ponorogo, bersifat transparan. Dalam pemasaran mempunyai nilai positif, memiliki pasar yang baik dan bermitra dengan perusahaan nestle di daerah Pasuruan, Sidoarjo, Jawa Timur. Praktik Pemasaran Susu Sapi ditinjau dalam hukum Islam, tidak menyimpang dari aturan agama Islam.Kendala yang dialami oleh peternak sapi perah didesa tambang, misalnya : belum ada petugas kesehatan yang secara khusus dan kurangnya koordinasi dan kerja sama antara pemerintahan desa Tambang dengan dinas kesehatan dalam membantu kesehatan masyarakat dan juga hewan ternak.
\end{abstract}

Kata Kunci : Pemasaran Susu Sapi, Hukum Islam, Ponorogo 


\section{PENDAHULUAN}

Manusia dalam melakukan muamalah selalu berinteraksi dengan orang lain, dan dalam memenuhi kehidupannya harus memberikan haknya sesuai dengan hak masing-masing atau berlaku secara adil yang berlandaskan pada syariat Islam. ${ }^{1}$ Salah satu hasil interaksi yang terjadi pada manusia dalam bermuamalah adalah jual beli. Muamalah merupakan bagian dari agama Islam, yakni mengatur hubungan antar manusia dalam masyarakat berkenaan dengan kebendaan dan kewajiban. ${ }^{2}$ Kegiatan jual beli ini dapat memenuhi kebutuhan yang diperlukan. Islam mengatur terkait hal ini, agar tidak menyimpang dari aturan yang telah ditetapkan Allah di dalam Al-Quran.

Al-Quran sebagai kitab terakhir dimaksudkan untuk menjadi petunjuk bagi seluruh umat manusia (hudan linnas) sampai akhir zaman. Bukan hanya diperuntukkan bagi anggota masyarakat Arab tempat dimana kitab ini diturunkan untuk seluruh umat manusia. Di dalamnya terkandung nilai-nilai yang luhur yang mencakup seluruh aspek kehidupan manusia dalam berhubungan dengan Tuhan maupun hubungan manusia dengan sesama manusia lainnya dan hubungan manusia dengan alam sekitarnya. ${ }^{3}$

Allah SWT berfirman dalam Al-Quran surat Al- Baqarah ayat 275 yang berbunyi:

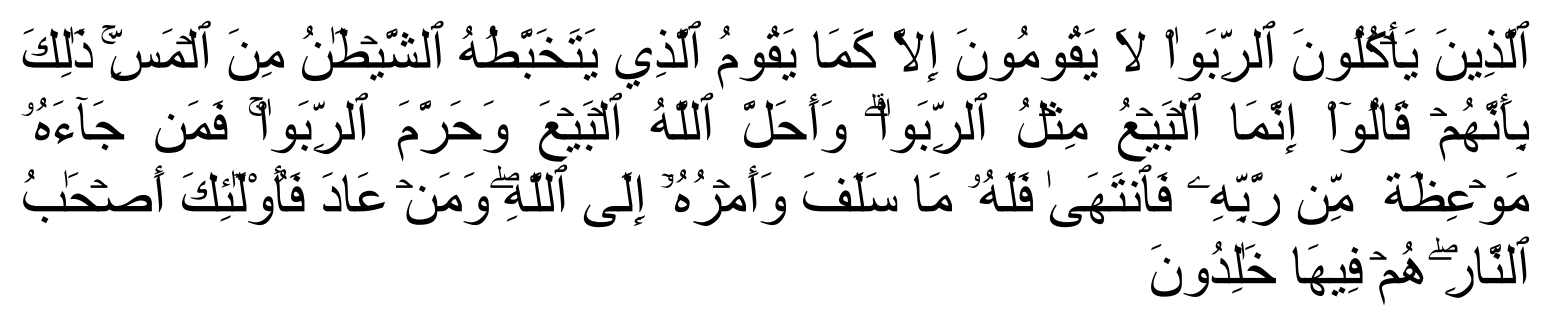

Artinya: " Orang - orang yan memakan riba tidak dapat berdiri melainkan seperti berdirinya orang yang kemasukan setan karena gila, yang demikian itu karena mereka berkata bahwa jual beli sama dengan riba. padahal Allah telah menghalalkan jual beli dan mengharamkan riba. Barang siapa yang mendapat peringatan dari Tuhannya, lalu dia berhenti, maka apa yang diperolehnya dahulu menjadi miliknya dan urusannya (terserah) kepada Allah. Barang siapa yang mengulangi, maka mereka itu penghuni neraka, mereka kekal didalamnya”. ( QS. Al- Baqarah : 275). ${ }^{4}$

Kehidupan masyarakat yang selalu berubah dan mengikuti perkembangan zaman, hal ini bisa mengakibatkan perilaku yang berbeda-beda disetiap zamannya. Dalam hal jual beli pun kadang terlupakan rukun dan syaratnya yang mengakibatkan batalnya proses jual beli tersebut.

\footnotetext{
${ }^{1}$ Ismail Nawawi, Fikih Muammalah Klasik Dan Kontemporer (Bogor : Ghalia Indonesia, 2012), hlm. 15.

${ }^{2}$ Ibid., hlm. 9.

${ }^{3}$ Studi Pendekatan Al-Quran Dalam Jurnal Thariqah Ilmiah Vol, 01, No. 01 Januari 2014, hlm. 33.

${ }^{4}$ Depag RI, Al-quran dan terjemahan, (Surabaya : Pustaka Harapan, 2006), QS. Al-Baqarah [2] : 275.
} 
Desa Tambang yang terletak di Kecamatan Pudak Kabupaten Ponorogo provinsi Jawa Timur, dengan suasana pegunungan yang asri sangat cocok bagi petani sayuran dan para peternak sapi. Terdapat beberapa anggota masyarakat yang mempunyai hewan ternak berupa sapi perah dan sapi biasa atau yang sering disebut dengan sapi jowo. Dengan adanya peternak sapi perah ini diharapkan dapat meningkatkan perekonomian di desa karena menghasilkan susu sapi yang mempunyai kualitas yang cukup baik. Di desa Tambang ini ada kelompok peternak sapi perah yang mana kelompok ini beranggotakan 20 peternak. Dimana disetiap pagi dan sorenya para peternak sapi memerah susu sapi dan hasilnya di jual kepada pengepul dengan harga yang sesuai dengan kualitas susu sapi yang telah disepakati bersama antara peternak dan pengepul.

Adanya pemasaran susu sapi di desa Tambang ini dapat membantu menumbuhkan perekonomian masyarakat dalam bidang peternakan sapi perah, dan melihat fenomena kejadian di lapangan maka desa Tambang memiliki potensi yang sangat besar dalam mengembangkan bisnis susu sapi perah, yang dapat meningkatkan pendapatan ekonomi masyarakat sekitar dan juga dapat menjalin mitra antara desa Tambang dengan perusahaan-perusahaan susu yang ada di Jawa Timur. Disamping itu juga dapat meningkatkan ukhuwah Islamiyah antara penjual dan pembeli. Oleh sebab itu penelitian ini bertujuan untuk mengetahui proses pemasaran susu sapi yang terjadi di desa Tambang dalam tinjauan hukum Islam.

\section{Definisi Pemasaran}

Pemasaran adalah sebuah proses kemasyarakatan di mana individu dan kelompok memperoleh apa yang mereka butuhkan dan inginkan dengan menciptakan, menawarkan, dan secara bebas mempertukarkan produk dan jasa yang bernilai dengan orang lain. ${ }^{5}$ Dengan adanya proses pemasaran ini maka kita dapat mengetahui dan memahami pelanggan dengan baik sehingga produk dan jasa bisa sesuai dengan kebutuhannya sehingga terjual sendiri. Idealnya, pemasaran harus menghasilkan seorang yang siap untuk membeli. Dengan demikian yang dibutuhkan hanyalah memastikan produk dan jasa tersedia. Yang biasa di pasarkan oleh orangorang pemasaran ada 10 tipe entitas : barang, jasa, acara, pengalaman, orang, tempat, property (hak kepemilikan), organisasi, informasi, dan ide. ${ }^{6}$

Di dalam memasarkan produk atau barang harus ada seseorang yang memasarkannya yang disebut dengan pemasar, pemasar bertanggung jawab atas manajemen permintaan, manajer pemasaran berusaha memengaruhi tingkat, waktu, dan komposisi permintaan untuk mencapai tujuan organisasi. Ada delapan keadaan permintaan yang mungkin terjadi:

a. Permintaan negatif, Konsumen tidak menyukai produk dan mungkin bahkan berusaha

\footnotetext{
${ }^{5}$ Philip Kotler dan Kevin Lane Keller, Manajemen Pemasaran, (Jakarta: Erlangga, 2019), hlm. 5.

${ }^{6}$ Ibid., hlm. 6
} 
menghidari;

b. Permintaan yang tidak ada, Konsumen mungkin tidak sadar akan atau tertarik pada produk;

c. Permintaan laten, Konsumen mungkin memiliki suatu kebutuhan yang kuat yang tidak bisa dipenuhi produk yang ada;

d. Permintaan yang menurun, Konsumen mulai jarang membeli produk atau tidak sama sekali;

e. Permintaan tidak teratur, Konsumen membeli secara musiman, bulanan, mingguan, harian, atau bahkan hitungan jam;

f. Permintaan penuh, Konsumen membeli semua produk yang dilempar ke pasar; dan

g. Permintaan tak sehat, Konsumen mungkin tertarik pada produk yang memiliki konsekuensi social yang tidak diinginkan.

Didalam kegiatan pemasaran setelah adanya barang yang dipasarkan atau sebuah produk, seorang pemasar (marketer), maka harus ada tempat untuk memasarkan produk tersebut yang mana disebut dengan pasar. Pasar adalah tempat fisik di mana pembeli dan penjual berkumpul untuk membeli dan menjual barang. Para ekonom mendeskripsikan pasar sebagai sekumpulan pembeli dan penjual yang bertransaksi atas suatu produk. ${ }^{7}$

\section{Konsep Pemasaran}

Tugas pemasaran bukanlah mencari pelanggan yang tepat untuk produk kita, melainkan menemukan produk yang tepat untuk pelanggan kita. Konsep pemasaran beranggapan bahwa kunci untuk mencapai tujuan organisasi adalah menjadi lebih efektif dari pada pesaing dalam menciptakan, menghatarkan, dan mengkomunikasikan nilai pelanggan yang lebih baik kepada sasaran yang dipilih.

Pemasaran merupakan sistem dari strategi bauran pemasaran dan strategi pemasaran itu sendiri merupakan sub sistem dari proses manajemen pemasaran. Dengan demikian dapat dikatakan bahwa strategi pemasaran menempati posisi tersendiri dalam ilmu pemasaran, tetapi menjadi satu kesatuan dalam strategi bauran pemasaran secara keseluruhan. Strategi pemasaran dapat dijelaskan dengan diawali bagaimana perusahaan menyiapkan suatu bauran penawaran yang terdiri dari produk, jasa, dan harga serta memanfaatkan bauran promosi yang terdiri dari promosi penjualan, periklanan, gugus wiraniaga, hubungan masyarakat, surat langsung dan pemasaran jarak jauh (telemarketing) untuk menjangkau saluran distribusi dan pelanggan akhir, Pemasaran meliputi aktivitas-aktivitas yang berkaitan dengan penjualan, pengiklanan, promosi

\footnotetext{
${ }^{7}$ Philip dan Keller, Manajemen, Op.Cit, hlm. 8.
} 
serta penentuan harga. Strategi pemasaran Online atau sering disebut dengan Online marketing strategy merupakan segala usaha (bisnis) yang dilakukan untuk melakukan pemasaran suatu produk atau jasa melalui atau menggunakan media online, yakni media internet. ${ }^{8}$ Jadi menggunakan media internet memudahkan kita untuk mempromosikan sehingga para pembeli sangat mudah untuk mendapatkan informasi tentang suatu produk yang dipromosikan melalui media online.

Konsep penjualan dimulai dari produk yang ada. Kemudian dilakukan penjualan dan promosi besar-besaran untuk mencapai penjualan yang menguntungkan. Konsep pemasaran dimulai dari konsumen sasaran dan kebutuhan serta keinginan mereka. Perusahaan mengintegrasikan dan mengkoordinir semua kegiatan yang dapat memberikan kepuasan konsumen.Perusahaan mencapai keuntungan dengan menciptakan dan mempertahankan kepuasan konsumen. Secara singkat konsep pemasaran berorientasi pada kebutuhan dan keinginan konsumen yang didukung oleh usaha pemasaran terpadu, yang diarahkan pada terciptanya kepuasan konsumen sebagai kunci tercapainya tujuan perusahaan. ${ }^{9}$

\section{Strategi Pemasaran}

Strategi pemasaran adalah pendekatan pokok yang akan digunakan oleh unit usaha dalam mencapai sasaran yang telah ditetapkan lebih dulu, didalamnya tercantum keputusan-keputusan pokok mengenai target pasar, penempatan produk pasar, bauran pemasaran, dan tingkat biaya pemasaran yang diperlukan. ${ }^{10}$

Dalam mengembangkan strategi apapun tentu saja seorang manajer produk harus membahasnya dengan pihak-pihak yang banyak mengetahui, seluk beluk pemasaran yang kerjasama dengannya akan sangat berarti dalam menentukan sukses atau gagalnya strategi tersebut. Dengan demikian ia akan mengajak bagian pembelian produk untuk membicarakan bersama mengenai kemungkinan tersedianya bahan baku atau bahan penolong yang memadai, serta kemampuan produksi yang sesuai dengan rencana penjualan. Selain itu ia akan menghubungi manajer penjualan untuk menjajagi tersedianya dukungan tenaga penjual dan juga manajer keuangan untuk mencari kepastian mengenai cukup tersedianya dana yang dibutuhkan.

Dalam peranan strategisnya, pemasaran mencakup setiap usaha untuk mencapai kesesuaian antara perusahaan dengan lingkungannya dalam rangka mencari pemecahan atas masalah penentuan dua pertimbangan pokok yaitu bisnis apa yang akan digeluti, dan bagaimana bisnis yang telah dipilih tersebut dapat dijalankan dengan sukses dalam lingkungan yang kompetitif atas

8 Ira Setiawati dan Penta Widyartati,"Pengaruh Strategi Pemasaran Online Terhadap Peningkatan Laba UMKM" dalam Bingkai Manajemen 2017

${ }^{9}$ Mohammad Kanzunnudin, "Konsep Penjualan Versus Konsep Pemasaran” dalam Fokus Ekonomi Vol. 4 No. 2 Desember 2009: 1 - 8

${ }^{10}$ Danang Sunyoto, Strategi Pemasaran (Jakarta : Center for Academic Publishing Sevice, 2015), hlm. 2. 
dasar perspektif produk, harga, promosi, dan distribusi untuk melayani pasar sasaran.

Strategi pemasaran terdiri atas lima elemen yang saling berkaitan, yaitu:

a. Pemilihan Pasar, yaitu memilih pasar yang akan dilayani. Keputusan ini didasarkan pada faktor-faktor : persepsi terhadap fungsi produk dan pengelompokan teknologi yang dapat diproteksi dan didominasi, keterbatasan sumber daya internal yang mendorong perlunya pemusatan yang lebih sempit, pengalaman komulatif yang didasarkan pada trial dan error di dalam menanggapi peluang dan tantangan, kemampuan khusus yang berasal dari akses terhadap sumber daya langka atau pasar terproteksi.

b. Perencanaan produk, meliputi produk spesifik yang dijual, pembentukan lini produk, dan desain penawaran individual pada masing-masing lini. Produk itu sendiri menawarkan manfaat total yang dapat diperoleh pelanggan dengan melakukan pembelian. Manfaat tersebut meliputi produk, merek produk, ketersediaan produk, jaminan atau garansi, jasa reparasi, dan bantuan teknis yang disediakan penjual, serta hubungan personal yang mungkin terbentuk di antara pembeli dan penjual.

c. Penetapan harga, yaitu menentukan harga yang dapat mencerminkan nilai kuantitatif dari produk kepada pelanggan.

d. Sistem distribusi, yaitu saluran perdagangan grosir dan eceran yang dilalui produk hingga mencapai konsumen akhir yang membeli dan menggunakannya.

e. Komunikasi pemasaran (Promosi) yang meliputi periklanan, personal selling, promosi penjualan, direct marketing, dan public relations. ${ }^{11}$

Dalam strategi pemasaran terdapat dua kebutuhan, yaitu kebutuhan primer dan kebutuhan selektif. Kebutuhan primer adalah kebutuhan akan bentuk atau kelas produk atau jasa dasar. Sedangkan kebutuhan selektif adalah kebutuhan akan produk atau merek perusahaan tertentu. Dalam memanfaatkan kedua kebutuhan tersebut, bagi perusahaan dapat menggunakan stategi, yaitu strategi kebutuhan primer dan kebutuhan selektif. Ada beberapa informasi yang dapat digunakan sebagai dasar untuk memilih strategi pemasaran yang terbaik, yaitu strategi harus konsisten dengan sasaran produk, dan masalah serta peluang mengenai kebutuhan pembeli, ukuran pasar,dan kemampulabaan harus ditentukan dari analisis situasi.

\begin{tabular}{|l|l|}
\hline \multicolumn{1}{|c|}{ Sasaran Produk } & \multicolumn{1}{|c|}{ Strategi Pemasaran Yang Lazim } \\
\hline Mencapai tingkat penjualan yang memadai & Primer : meningkatkan jumlah pemakai \\
\hline $\begin{array}{l}\text { Mencapai bagian pasar yang memadai } \\
\text { (untuk merek baru) }\end{array}$ & Selektif : penjaringan pelanggan \\
\hline
\end{tabular}

${ }^{11}$ Ibid, hlm. 5. 


\begin{tabular}{|l|l|}
\hline Pertumbuhan bagian pasar & Selektif : penjaringan pelanggan \\
\hline Memelihara bagian pasar & $\begin{array}{l}\text { Selektif : mempertahankan pelanggan } \\
\text { yang baru bagi pasar }\end{array}$ \\
\hline Maksimal arus kas & $\begin{array}{l}\text { Selektif : mempertahankan pelanggan; } \\
\text { Primer: menambah tingkat pembelian }\end{array}$ \\
\hline Memelihara kemampulabaan & $\begin{array}{l}\text { Selektif : mempertahankan pelanggan (di } \\
\text { segmen yang terbatas) }\end{array}$ \\
\hline Panen & $\begin{array}{l}\text { Selektif : mempertahankan pelanggan } \\
\text { (dengan usaha minimum) }\end{array}$ \\
\hline
\end{tabular}

Tabel diatas menunjukan strategi pemasaran yang sesuai untuk berbagai sasaran produk. $^{12}$

\section{Pemasaran dalam Konsep Islam}

Pemasaran adalah suatu aktivitas yang selalu dikaitkan dengan perdagangan. Jika meneladani Rasulullah SAW saat melakukan perdagangan, maka beliau sangat mengedapankan adab dan etika dagang yang luar biasa. Etika dan adab perdagangan inilah yang dapat disebut sebagai strategi dalam berdagang. Dalam melaksanakan jual beli perlu mengetahui rukun dan syaratnya.

\section{Rukun Jual Beli}

Rukun jual beli yaitu: adanya penjual dan pembeli, ada barang yang diperjualbelikan, ada kesepakatan harga terkait barang yang diperjualbelikan, dan adanya serah terima atau ijab qabul antara penjual dan pembeli.

\section{Syarat Jual Beli}

Syarat dalam jual beli yaitu :

a. Berakal. Pihak yang bertransaksi haruslah telah baligh, memiliki kemampuan mengatur uang, dan kompeten dalam melakukan jual beli.

b. Kehendak sendiri. Para pihak yang terlibat melakukan tranasaksi dengan ridha dan sukarela, karena jika dilakukan dengan paksaan, termasuk transaksi yang bathil (Q.S An-Nissa: 29).

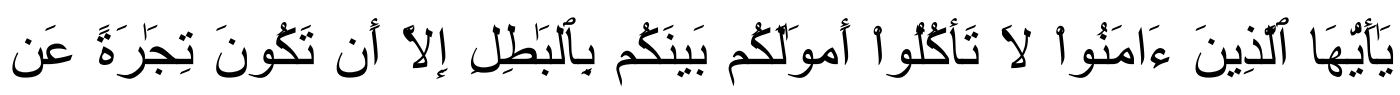

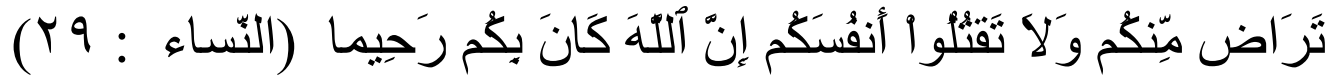

Artinya : "Hai orang-orang yang beriman, janganlah kamu saling memakan harta sesamamu dengan jalan yang batil, kecuali dengan jalan perniagaan yang berlaku dengan suka sama-suka di antara kamu. Dan janganlah kamu membunuh dirimu; sesungguhnya Allah adalah Maha Penyayang kepadamu." (Q.S An-Nissa: 29). ${ }^{13}$

\footnotetext{
${ }^{12}$ Sunyoto, Strategi, Op.Cit, hlm.12.
} 
c. Mengetahui. Para pihak telah mengetahui barang dan harga jualnya, tidak boleh ada ketidak jelasan (ghoror) seperti membeli susu yang masih belum diperah.

d. Suci barangnya. Barang yang diperjualbelikan bukan benda najis atau yang barang yang haram.

e. Barang bermanfaat. Barang pada transksi jual beli memiliki manfaat sehingga tidak mubazir.

f. Barang sudah dimiliki. Penjual telah memiliki hak untuk menjual barang tersebut, baik itu dengan telah membeli telebih dahulu dari suplier/produsen, atau telah memperoleh izin untuk menjual dari pemilik barang. (kecuali jika melakukan jual beli salam).

g. Barang dapat diserahterimakan. Barang yang tidak dapat diserahkan, seperti jual beli burung yang sedang terbang, berpotensi besar tidak terealisasi, sehingga menimbulkan kerugian pada salah satu pihak.

h. Ijab dan qabul transaksi harus berhubungan (tidak ada pemisah) meskipun berbeda tempat

i. Lafadz dan perbuatan jelas - pengucapan menjual dan membeli oleh para pihak harus jelas dan saling berkait, selain itu ijab qabul juga dapat dilakukan sesuai kebiasan perdagangan setempat, seperti menyerahkan uang dan penjual menyerahkan barang.

\section{Hal-hal yang merusak pemasaran}

Sesuatu yang merusak terjadinya jua beli atau merusak ke absahan dalam melaksanakan jual beli adalah meninggalkan salah satu rukun dari jual beli. Ketika dalam pemasaran yang dapat merusak pemasaran adalah ketika harga yang ditawarkan tidak sesuai dengan kesepakatan antara penjual satu dan yang lainnya, berbeda harga dapat merusak pemasaran, menipu dalam bertransaksi.

Ada beberapa etika yang harus dijunjung pedagang muslim dalam menjalankan aktivitas jual-beli sebagai berikut:

a. Tidak menjual sesuatu yang haram. Umat Islam dilarang menjual sesuatu yang haram seperti minuman keras yang memabukkan, narkotika dan barang-barang yang diharamkan Allah SWT. Hasil penjualan barang-barang itu hukumnya haram dan kotor.

b. Tidak melakukan sistem perdagangan terlarang. Contohnya menjual barang yang tidak ada dan menjual hewan yang belum dilahirkan. Rasulullah SAW bersabda: 29.

${ }^{13}$ Depag RI, Alqur'an dan Terjemahan, (CV. Pustaka Agung Harapan: Surabaya, 2006), Q.S An-Nissa[4] : 


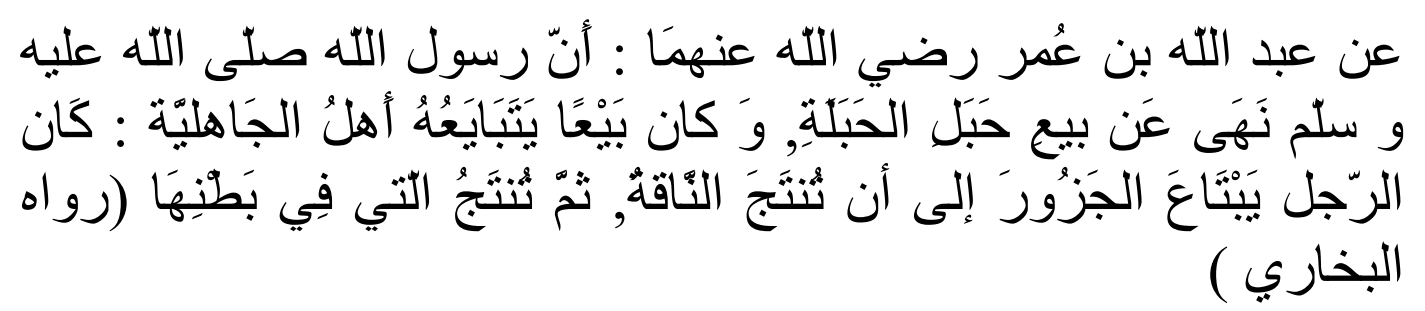

Artinya: " Diriwayatkan dari Abdullah bin Umar r.a bahwa Rasulullah SAW melarang penjualan hewan yang disebut Habalulhabalah seperti yang berlaku pada masa jahiliyyah, yaitu seseorang yang membayar harga seekor onta yang belum dilahirkan dan onta yang masih dalam kandungan”. (HR. Al Bukhari, nomor hadis : 2134) ${ }^{14}$

c. Tidak membiasakan bersumpah ketika berdagang. Hal ini sesuai dengan hadits Rasulullah SAW : “janganlah kalian banyak bersumpah ketika berdagang, sebab cara seperti itu melariskan dagangan lalu menghilangkan keberkahan. Nabi Muhammad Shallallahu'alaihi Wasallam bersabda:

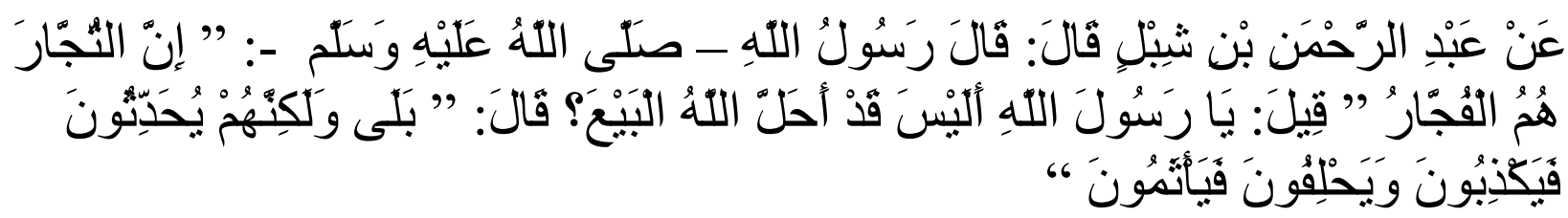

Artinya: Dari 'Abdurrahman bin Syibel, ia berkata: Rasulullah Shallallahu'alaihi Wasallam bersabda: "Para pedagang adalah tukang maksiat". Diantara para sahabat ada yang bertanya: "Wahai Rasulullah, bukankah Allah telah menghalalkan jual-beli?”. Rasulullah menjawab: "Ya, namun mereka sering berdusta dalam berkata, juga sering bersumpah namun sumpahnya palsu.

d. Tidak berbohong ketika berdagang. Salah satu perbuatan berbohong adalah menjual barang yang cacat namun tidak diberitahukan kepada pembelinya.

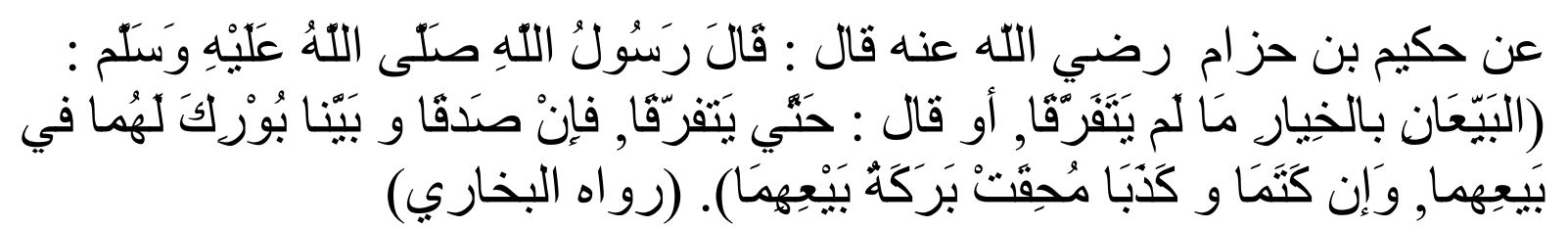

Artinya: "Diriwayatkan dari hakim bin Hizam ra, dia berkata: Rasulullah SAW pernah bersabda, " penjual dan pembeli memiliki hak khiyar (tetap melanjutkan jual beli atau membatalkannya) selama keduanya belum berpisah,jika keduanya berkata benar dan menjelaskan apa adanya, maka jual beli mereka diberkahi, tetapi jika keduanya menyembunyikan cacatyang ada dan berkata dusta,maka jual beli mereka tidak diberkahi." ( HR. Al Bukhari) ${ }^{15}$

e. Penjual harus memyempurnakan timbangan. Seorang pedagang sangat dilarang mengurangi timbangan. Allah SWT berfirman dalam al-qur'an surat Al-Syu'ara ayat 181-183, sebagai berikut:

\footnotetext{
${ }^{14}$ Imam Az-Zabidi, Ringkasan Hadis Shahih Al Bukhari (Jakarta : Pustaka Amani, 2002), hlm. 465.

${ }^{15}$ Ibid, hlm. 453.
} 


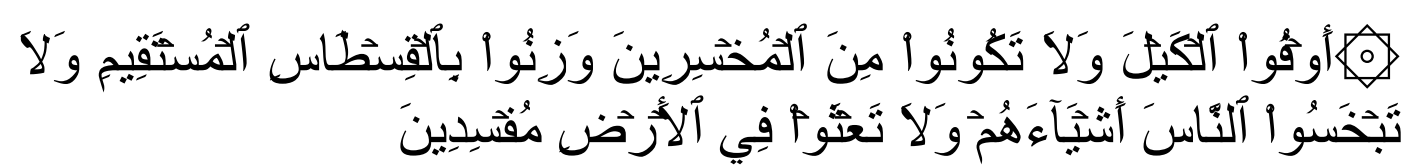

Artinya:"Sempurnakanlah takaran dan janganlah kamu merugikan orang lain, dan timbanglah dengan timbangan yang benar, dan janganlah kamu merugikan manusia dengan mengurangi hak-haknya dan janganlah membuat kerusakan di bumi.” ( QS. Al-Syu'ara : 181-183). ${ }^{16}$

f. Pemaaf, mempermudah dan lemah lembut dalam berjual beli

g. Tidak boleh memakan dan memonopoli barang dagangan tertentu. Sabda Nabi Shallallahhu 'alaihi wa sallam: "tidaklah seorang menimbun barang melainkan pelaku maksiat". (HR Muslim). ${ }^{17}$

Allah SWT berfirman dalam surat al hajj ayat 25 sebagai berikut :

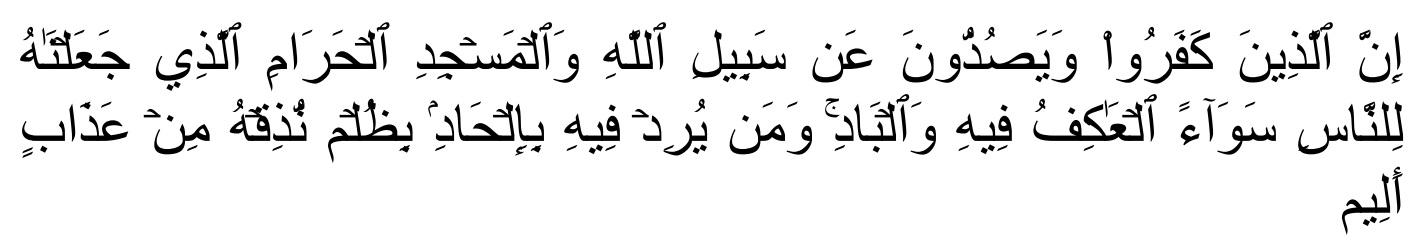

Artinya: Sesungguhnya orang-orang yang kafir dan yang menghalangi (manusia) dari jalan Allah dan masjidilHaram yang telah kami jadikan terbuka untuk semua manusia, baik yang bermukim disana maupun yang datang dari luar dan siapa saja yang bermaksud di dalamnya, niscayaakan kami rasakan kepadanya siksa yang pedih. (QS A1 Hajj : 25 ). ${ }^{18}$

Dalam Islam ada empat karakteristik pemasaran atau syariah marketing yang dapat menjadi panduan bagi pemasar yaitu:

a. Teistis (Rabaniyyah)

Salah satu ciri khas pemasaran syariah yang tidak dimiliki dalam pemasaran konvensional yang dikenal selama ini adalah sifatyang religious (dinniyah). Kondisi ini tercipta tidak karena keterpaksaan, tetapi berangkat dari kesadaran akan nilai-nilai religious, yang dipandang penting dan mewarnai aktivitas pemasaran agar tidak terperosok ke dalam perbuatan yang dapat merugikan orang lain. Jiwa seorang pemasar syariah meyakini bahwa hukum-hukum syariat yang teistis atau bersifat ketuhanan ini adalah hukum yang paling sempurna. Seorang syariah marketer meyakini bahwa adanya Allah Ta'ala selalu dekat dan mengawasinya ketika dia sedang melaksanakan segala macam bisnis. Dia pun yakin bahwa Allah Ta'ala akan meminta pertanggungjawaban darinya atas pelaksanaan syariat itu pada hari ketika semua dikumpulkan untuk diperlihatkan amal-amalnya (dihari kiamat).

b. Etis (Akhlaqiyyah)

\footnotetext{
${ }^{16}$ Depag RI, Al Qur'an dan Terjemahan, (CV. Pustaka Harapan, 2006), QS. Al-Syu'ara [26] : 181-183.

${ }_{17}$ Hamdi Agustin, Studi Kelayakan Bisnis Syariah (Depok : PT Raja Grafindo Persada, 2017), hlm. 88.

${ }^{18}$ Depag RI, Al Qur'an dan Terjemahan, (CV. Pustaka Harapan, 2006), QS Al Hajj [22] : 25.
} 
Sifat etis ini sebenarnya merupakan turunan dari sifat teitis. Dengan demikian, syariah marketing adalah konsep pemasaran yang sangat megedepankan nilai-nilai moral dan etika, tidak peduli apa pun agamanya. Karena nilai etika adalah nilai yang bersifat universal yang diajarkan oleh semua orang.

Untuk mencapai tujuan tersebut, Allah Ta'ala, memberikan petunjuk melalui para rasulNya yang meliputi segala sesuatu yang dibutuhkan manusia, baik akidah, akhlah (moral,etika), maupun syariah. Dua komponen pertama, akidah dan akhlak bersifat konstan, keduanya tidak mengalami perubahan apapun dengan berbedanya waktu dan tempat. Sedangkan syariah senantiasa berubah sesuai dengan kebutuhan dan taraf peradaban manusia.

c. Realistis (Al-Waqi'iyyah)

Realistis (Al-Waqi'iyyah) syariah marketing bukanlah konsep yang eksklusif, fanatic, antimodernitas, dan kaku. Syariah marketing adalah konsep pemasaran yang fleksibel, sebagaimana keluwesan syariah Islamiyah yang melandasinya.

Syariah marketer bukanlah para pemasar itu harus berpenampilan ala bangsa Arab dan mengharamkan dasi karena dianggap merupakan simbol masyarakat barat. Syariah marketer adalah pemasar professional dengan penampilan yang bersih, rapi, dan bersahaja, apapun model atau gaya berpakaian yang dikenakannya. Mereka bekerja dengan profesional dan mengedepankan nilai-nilai religius, kesalehan, aspek moral, dan kejujuran dalam segala aktivitas pemasarannya.

d. Humanistis ( Al-Insaniyyah)

Humanistis (Al-Insaniyyah) adalah bahwa syariah diciptakan untuk manusia agar derajatnya terangkat, sifat kemanusiaaannya terjaga dan terpelihara. Dengan memiliki nilai humanistis ia menjadi manusia yang terkontrol, dan seimbang (tawazun), bukan manusia serakah, yang menghalalkan segala cara untuk meraih keutungan yang sebesar-besarnya. Bukan menjadi manusia yang bahagia di atas penderitaan orang lain atau manusia yang kering dengan kepedulian sosial.

Syariat Islam adalah syariah humanistis (insaniyyah). Syariat Islam diciptakan untuk manusia sesuai dengan kapasitasnya tanpa menghiraukan ras, warna kulit,, kebangsaan, dan status. Hal inilah yang membuat syariah Islam memiliki sifat universal sehingga menjadi syariat humanistis universal. ${ }^{19}$

\footnotetext{
${ }^{19}$ Hamdi Agustin, Studi Kelayakan Bisnis Syariah (Depok : PT Raja Grafindo Persada, 2017), hlm. 90.
} 
Pemasaran syariah dijalankan berdasarkan konsep keislaman yang diajarkan Rasulullah SAW, jadi nilai inti pemasaran syariah adalah integritas, dan transparansi, sehingga marketer tidak boleh bohong dan orang membeli karena kebutuhan dan sesuai dengan keinginan, bukan karena diskonnya atau iming-iming hadiah belaka.

\section{METODE PENELITIAN}

\section{Desain Penelitian}

Desain penelitian ini menggunakan studi kasus atau case study yaitu prosedur dan teknik penelitian tentang subjek yang diteliti berupa Peternak Sapi Perah, Pengepul Susu Sapi, dan Pembuat Makanan Ringan yang bahan utamanya dari susu sapi di desa Tambang kecamatan Pudak Kabupaten Ponorogo. Bertujuan untuk memperoleh gambaran terperinci tentang latar belakang, sifat, karakter yang khas dari kasus, penggunaan studi kasus dikarenakan strategi yang dikeluarkan tidak dapat diaplikasikan oleh unit usaha peternakan lain disebabkan oleh permasalahan internal dan faktor pemasaran yang berbeda.

\section{Populasi dan Sampel}

Penelitian ini dilakukan di Desa Tambang, Kec. Pudak, Kab. Ponorogo, yang dijadikan objek adalah Peternak Sapi Perah, Pengepul Susu Sapi, dan Pembuat Makanan Ringan yang bahan utamanya dari susu sapi.

\section{Metode Pengumpulan Data}

Metode pengumpulan data yang dapat memungkinkan diperolehnya data yang obyektif. Di bawah ini peneliti akan menguraikan beberapa teknik untuk mengumpulkan data, yaitu:

a. Metode Observasi

Teknik pengumpulan data mempunyai ciri yang spesifik bila dibandingkan dengan teknik yang lain, yaitu wawancara dan kuesioner. ${ }^{20}$ Di dalam metode ini peneliti mengamati upaya yang dilakukan Peternak sapi perah dalam proses peternakan dan pemasaran susu sapi di Desa Tambang, Kecamatan Pudak, Kabupaten Ponorogo.

Metode ini sebagai data pendukung dari data yang diperoleh dari hasil wawancara, sehingga dapat diketahui kebenaran antara hasil wawancara dengan kenyataan yang terjadi dilapangan.

b. Metode Wawancara

Wawancara adalah sebuah pertukaran informasi verbal, tatap muka, walaupun sebagian orang ada yang menggunakan komunikasi telepon. Dalam wawancara mencoba untuk

\footnotetext{
${ }^{20}$ Sugiyono, Metode Penelitian Pendidikan (Bandung: Alfabeta, 2015), hlm. 203.
} 
mendapatkan informasi, keyakinan atau pendapat dari orang lain. ${ }^{21}$ Metode ini digunakan untuk menggali data tentang upaya yang dilakukan Peternak sapi perah dalam proses pemasaran susu sapi di Desa Tambang, Kecamatan Pudak, Kabupaten Ponorogo.

Dalam wawancara menggunakan dua jenis pertanyaan, pertanyaan berstruktur dan pertanyaan terbuka. Pertanyaan berstruktur yaitu membatasi respoden dalam memberikan jawaban kepada beberapa alternative saja ataupun kepada satu jawaban saja, pertanyaan berstruktur digunakan untuk mengetahui hirarki yang akan dipakai dalam melakukan penelitian. Pertanyaan terbuka yaitu pertanyaan yang dibuat dengan memberikan kebebasan kepada responden dalam menjawab pertanyaan, atau tidak terikat dengan beberapa alternatif jawaban, pertanyaan terbuka digunakan untuk mengetahui gambaran umum desa Tambang dan bagaimana pemasaran yang telah dilakukan oleh peternak sapi perah di desa Tambang Pudak Ponorogo.

\section{HASIL DAN PEMBAHASAN}

\section{Praktik Pemasaran Susu Sapi di Desa Tambang}

a. Sebelum menyetorkan kepada pengepul susu sapi, para peternak melakukan beberapa hal agar mendapatkan kualitas susu sapi yang bagus, mulai dari perawatan, pembersihan kandang, serta waktu-waktu yang tepat untuk melakukan pemerasan susu sapi

b. Perawatan sapi, dengan memberikan makan yang baik dari rumput dan juga sentrat dengan cara memberikan makan yang teratur

c. Sebelum memeras susu sapi para peternak membersihkan kandang dan juga sapi nya tersebut agar bersih setelah bersih peternak membersihkan putting susu sapi agar mudah untuk memeras susu sapi. Susu sapi ditempatkan didalam tempat khusus susu sapi. Peternak sapi memeras susu sapi pada pagi dan sore hari.

d. Setelah itu susu sapi langsung disetorkan ke pengepul, para peternak sapi mengunakan kendaraan roda dua yang telah didesain khusus untuk membawa hasil perasan susu sapi tersebut ke pengepul susu sapi.

e. Ketika ditempat pengepul susu sapi para peternak sapi bertemu langsung kepada pengepul dan langsung melakukan penimbangan susu sapi yang dibawa oleh para peternak sapi perah tersebut dengan alat khusus yang dimiliki oleh pengepul susu sapi, dengan menggunakan alat tersebut pengepul bisa mengetahui kualitas susu yang dibeli dari peternak sapi perah.

${ }^{21}$ Khairudin Kurniawan, Metodelogi Penelitian Bahasa \& Sastra Indonesia, (Bandung: Pustaka Setia, 2018), hlm. 133. 
f. Memasukan susu tersebut kedalam penampungan susu sapi yang telah di desain khusus untuk menjaga kualitas susu sapi agar tetap baik. Karena setelah terkumpul susu sapi akan diambil oleh nestle, perusahaan tersebut yang memerlukan susu sapi yang baik untuk diproduksi menjadi olahan minuman yang terbuat dari susu sapi. Nestle mengambil susu sapi dari desa tersebut menggunakan kendaraan khusus untuk membawa susu sapi.

g. Pada saat transaksi peternak sapi perah melakukan akad jual beli kepada pengepul, dengan pembayaran di awal bulan setiap tanggal 5 (lima) dengan rata pendapatan. Peternak sapi perah dalam satu bulan dapat mencapai 10 juta, jika dipotong dengan pembiayaan lain maka pendapatan secara bersih untuk peternak 5 sampai 6 juta perbulan.

Dengan ini dapat meningkatkan perekonomian yang ada didesa tambang khususnya para peternak sapi perah. Walaupun mendapatkan pendapatan yang cukup besar dalam satu bulannya para peternak sapi perah masih merasakan suka dukanya dalam menjalankan atau menggeluti aktivitas sebagai peternak sapi perah. Dalam sukanya bisa mendapatkan pengahasilan tambahan selain berkebun dalam waktu satu bulan bisa mencapai 5 jutaan, dan dapat membantu perekonomian dalam memenuhi kebutuhan sehari-hari khususnya kebutuhan sehari-hari. Sedangkan duka yang dialami oleh peternak sapi perah yaitu ketika sapi perah tersebut sakit maka para peternak sapi mulai resah karena sapi tersebut menghasilkan kualitas susu yang kurang baik, dengan kualitas menurun maka pendapatan pun akan menurun, selain itu bagi yang pemula merintis ternak susu sapi kebingungan untuk mengatasi jika sapinya sakit, dan cara pemeliharaan serta memberi makannya.

Untuk saat ini belum ada dokter hewan yang ada dan siap didesa ketika ada hewan sapi yang sakit, saat ini masih diurusi secara mandiri. Yang dapat dilakukan bagi pemula yaitu bertanya kepada yang sudah lama menjalankan aktivitas bagi seorang peternak sapi perah, dengan adanya kegiatan ini maka akan menumbuhkan rasa sosial yang tinggi terhadap tetangga khususya bagi para peternak susu sapi perah. Didesa tambang ini para peternak sapi perah memiliki kelompok ternak sendiri-sendiri yang mana dibagi menjadi dua kelompok, yang beranggotakan sekitar 20 peternak sapi perah.

Yang menjadi tempat penampungan susu sapi berada di desa Bareng kecamatan Pudak kabupaten Ponorogo, yang bernama DAS Pos Penampungan Susu Bareng Agung Sejahtera. Ditempat tersebut para peternak susu sapi perah menyerahkan susu sapinya ketika pagi tempat penampungan tersebut menerima susu sapi mulai jam 06.30 - 07.00 WIB dan sore hari mulai jam 16.30 - 17.00 WIB, dari penampungan dapat menentukan harga susu sapi tersebut dengan melihat 
kualitas yang ada dalam susu tersebut.

Dari perusahaan menginginkan tempat penampungan yang steril. Dalam transaksi antara peternak sapi dan pengepul susu sapi dengan menggunakan sistem pembayaran perbulan, harga susu sapi per liter Rp. 5800. Setelah para peternak menyetorkan hasil perasan susu sapinya maka dari penampung akan salurkan kembali kepada perusahaan dalam bidang susu yaitu nestle, Pasuruan, jawa timur. Kemudian akan diolah menjadi berbagai macam produk yg berasal dari susu sapi, untuk pengambilannya dengan menggunakan kendaraan khusus yang mempunyai kapasitas yang cukup tinggi, yang dapat menampung 6000 - 7000 liter susu sapi. Dengan ini dari pos penampungan susu telah melakukan hubungan mitra dengan perusahaan nestle, bertujuan mendapatkan kualitas stok susu yang bagus dan juga membantu perekonomian yang ada didesa tambang dan sekitarnya khususnya para peternak susu sapi perah. ${ }^{22}$

Adapun persyaratan penerimaan susu sapi di DAS Pos Penampungan Susu Bareng Agung Sejahtera sebagai berikut:

1. Alkohol Test $76 \%$ negative

2. BJ Minimum pagi 1,024 dan sere 1,023

3. Tidak ada pemalsuan

4. Tidak mengandung antibiotik

5. Suhu minimal $30 \square^{23}$

\section{Keunggulan dan kelemahan Pemasaran Susu Sapi di Desa Tambang}

Setelah peneliti melakukan penelitian tentang pemasaran susu sapi di Desa Tambang maka peneliti ingin menguraikan keunggulan dan kelemahan pemasaran susu sapi sebagai berikut:

\section{Keunggulan}

a. Memiliki Pasar yang cukup baik;

b. Untuk persediaan makanan sapi perah mudah didapatkan;

c. Interaksi sosial antara peternak dan pengepul susu sapi perah baik;

d. Suasana desa tersebut mendukung dalam membantu meningkatkan kulitas susu sapi;

e. Harga susu sapi stabil;

f. Peternak memiliki etos kerja yang sangat baik dalam memelihara dan menjaga kualitas susu sapi; dan

g. Memiliki kerja sama dengan perusahaan Nestle.

\footnotetext{
22 Thohari, Wawancara, Desa Bareng, 31 April 2019.

${ }^{23}$ Peraturan Tertulis, CV Bareng Agung Sejahtera, Desa Bareng, 31 April 2019.
} 


\section{Kekurangan}

a. Belum ada pengecekan secara langsung dari dinas kesehatan secara berkala untuk sapi perah;

b. Mengunakan cara tradisional untuk menghasilkan susu sapi tersebut dengan memeras susu sapi dengan cara manual;

c. Belum adanya produk yang dihasilkan dari susu sapi tersebut untuk kontribusi dalam meningkatkan hasil pendapatan selain dari susu murni saja;

d. Belum memiliki kandang yang steril khusus rumah sapi perah;

e. Limbah kotoran sapi belum bisa dimanfaatkan secara baik;

f. Kurangnya peminat masyarakat untuk menjadi seorang peternak susu sapi perah;

g. Belum adanya dokter hewan yang ada di desa tersebut karena keberadaannya dapat membantu dalam merawat kesehatan sapi perah.

\section{Praktik Pemasaran Susu Sapi di Desa Tambang Dalam Perspektif Hukum Islam}

Didalam praktiknya kegiatan yang dilakukan oleh para peternak sapi perah menjualkan barang berupa susu sapi murni tanpa ada tambahan air ataupun yang lainnya, antara peternak dan pengepul susu sapi bertemu langsung tanpa ada pihak kedua, melakukan transaksi dengan terbuka secara transparan perihal kualitas susu sapi, harga maupun timbangan yang dilakukan oleh pengepul. Dalam proses pembayarannya sudah disetujui antara kedua belah pihak pembayaran harga atau hasil penjualan dari susu sapi tersebut akan dibayarkan setiap bulan tanggal 5 (Lima). Dalam praktik pemasaran sudah memiliki pasar tetap dan juga memperhatikan kebutuhan yang dibutuhkan oleh peternak sapi serta kehalalan produk yang dipasarkan.

Didalam praktik pemasaran susu sapi jauh dari perbuatan yang dapat merugikan peternak dan juga pengepul dengan tidak ada kecurangan, suap, memanipulasi permintaan atau penawaran. Praktik dalam pemasaran susu sapi menggunakan barang yang halal untuk dikonsumsi, memiliki manfaat, barang yang dijual adalah milik sendiri, tidak didapatkan dengan cara mencuri melainkan dari hasil usaha sendiri.

Rasulullah SAW Bersabda :

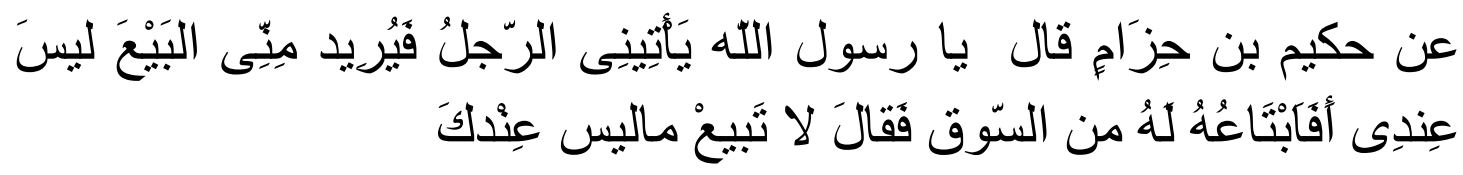

Artinya: Dari Hakim bin Hizam, "Beliau berkata kepada Rasulullah SAW, Wahai Rasulullah, ada orang yang mendatangiku. Orang tersebut ingin mengadakan transaksi jual beli denganku barang yang belum aku miliki bolehkah aku membelikan barang tertentu yang dia inginkan dipasar setelah bertransaksi dengan orang tersebut? Kemudian, Nabi Bersabda: janganlah kau menjual barang yang belum kau miliki. (HR. Abu Daud, No. 3505, dinilai shahih oleh Al-Bani). 
Kemudian Rasulullah SAW bersabda tentang pekerjaan yang terbaik adalah dari usaha sendiri, yaitu:

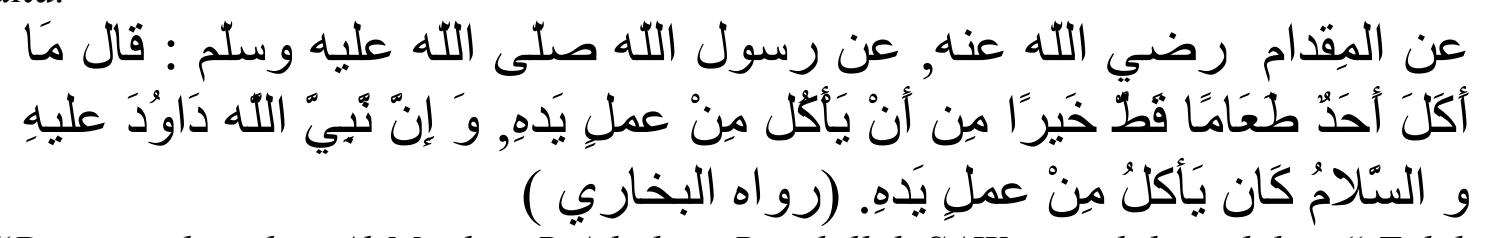

Artinya: "Diriwayatkan dari Al Miqdam R.A bahwa Rasulullah SAW pernah bersabda: "Tidak ada makanan yag lebih baik bagi seseorang dari pada makanan yang dihasilkan oleh kerja kerasnya sendiri. Sesungguhnya Nabi awud A.S makan dari hasil kerjanya sendiri." ( HR. Al Bukhari, Nomor Hadits 2070)24

\section{KESIMPULAN}

Dari hasil penelitian yang telah dilakukan dapat ditarik kesimpulan :

1. Strategi pemasaran susu sapi di desa Tambang, Kecamatan Pudak Kabupaten Ponorogo, dalam pemasaran peternak tetap menjaga kualitas susu sapi dengan menjaga kebersihan kandang sapi dan memberikan makanan yang dapat menunjang kualitas susu sapi yang dihasilkan dari sapi tersebut, transaksi penjualan yang dilakukan peternak sapi bersifat transparan.

2. Dalam pemasaran susu sapi di desa Tambang, Kecamatan Pudak Kabupaten Ponorogo mempunyai nilai positif diantaranya, memiliki pasar yang baik untuk memasarkan susu sapi dan mempunyai hubungan mitra dengan perusahaan nestle yang berada di daerah Pasuruan, Sidoarjo, Jawa Timur. Disamping itu juga, belum adanya produk yang dihasilkan dari susu sapi yang dikelola secara mandiri oleh desa Tambang, bertujuan untuk meningkatkan pemasaran susu sapi dan perekonomian di desa Tambang Pudak Ponorogo.

3. Praktik Pemasaran Susu Sapi ditinjau dalam hukum Islam, tidak menyimpang dari aturan agama Islam. Misalnya, barang yang dipasarkan adalah barang yang halal untuk dikonsumsi, dalam menjaga kualitas susu sapi tidak mencampurkan bahan pengawet, harga yang ditentukan tidak merugikan kedua belah pihak dalam menjualkan susu sapi tidak dicampur dengan air.

Kendala yang dialami oleh peternak sapi perah didesa tambang sebagai berikut :

1. Peternak sapi perah kurang terbantu dalam menjaga dan merawat kesehatan sapi perah di desa Tambang, karena belum ada petugas kesehatan yang secara khusus menangani permasalahan tersebut.

2. Kurangnya koordinasi dan kerja sama antara pemerintahan desa Tambang dengan dinas

\footnotetext{
${ }^{24}$ Imam Az-Zabidi, Ringkasan Hadis Shahih Al Bukhari (Jakarta : Pustaka Amani, 2002), hlm. 452.
} 
kesehatan dalam membantu kesehatan masyarakat dan juga hewan ternak.

\section{DAFTAR PUSTAKA}

Az-Zabidi, Imam. 2002. Ringkasan Hadis Shahih Al Bukhari. Jakarta : Pustaka Amani Agustin, Hamdi. 2017. Studi Kelayakan Bisnis Syariah. Depok : Raja Grafindo Persada 
Depag RI. 2006. Al Qur'an dan Terjemahan. Surabaya : Pustaka Harapan

Kanzunnudin, Mohammad. 2009. "Konsep Penjualan Versus Konsep Pemasaran" dalam Fokus Ekonomi Vol. 4 No. 2 Desember 2009

Kotler, Philip dan Kevin Lane Keller. 2019. Manajemen Pemasaran. Jakarta: Erlangga

Kurniawan, Khairudin. 2018. Metodelogi Penelitian Bahasa \& Sastra Indonesia. Bandung : Pustaka Setia

Nawawi, Ismail. 2012. Fikih Muammalah Klasik Dan Kontemporer. Bogor : Ghalia Indonesia

Setiawati, Ira dan Penta Widyartati,"Pengaruh Strategi Pemasaran Online Terhadap Peningkatan Laba UMKM" dalam Bingkai Manajemen 2017

Sugiyono. 2015. Metode Penelitian Pendidikan. Bandung: Alfabeta

Sunyoto, Danang. 2015. Strategi Pemasaran. Jakarta : Center for Academic Publishing Sevice 